\title{
Seminavis recta comb. nov. et stat. nov.: morphology and distribution in salt marshes from southern Brazil
}

\author{
Dávia Talgattir ${ }^{1}$ Lucielle M. Bertolli $^{1}$ \& Lezilda C. Torgan ${ }^{1,2}$
}

\begin{abstract}
${ }^{1}$ Programa de Pós-Graduação em Botânica, Universidade Federal do Rio Grande do Sul, Avenida Bento Gonçalves nº 9500, Campus do Vale, CEP 91501-970, Porto Alegre, RS, Brazil; e-mail: daviatalgatti@gmail. com

${ }^{2}$ Fundação Zoobotânica do Rio Grande do Sul, Museu de Ciências Naturais, Rua Doutor Salvador França, 1427, Jardim Botânico, CEP 90690-000, Porto Alegre, RS, Brazil
\end{abstract}

\begin{abstract}
Cymbella (Encyonema) grossestriata var. recta was studied based on analysis of the type material from Argentina and newly collected material from southern Brazil. In light microscopy the taxon presents dorsiventral valves, asymmetric and expanded central area, striae slightly radiate at the ends, becoming strongly radiate, and sigmoid in the center of valve. In scanning electron microscopy it is possible to observe features that are similar to the Navicula genus, such as slit-like areolae, accessory rib in the primary side, which is wider (expanded) at the center and valves with a marked virgae. Beyond these features the presence of two chloroplasts per cell definitively excludes the taxon from the Cymbellales group and allows us to transfer it to the genus Seminavis. Seminavis recta comb. et stat. nov. was found associated to Spartina and Scirpus species and living in the sediment of salt marshes in oligo to mesohaline zones, in a wide range of temperature and $\mathrm{pH}$. This species is rare, and has been reported only to South America until now.
\end{abstract}

Key words: brackish water, Cymbella (Encyonema) grossestriata var. recta, diatom, epiphyton, Navicula norae, sediment

\section{INTRODUCTION}

Seminavis, described by Mann in Round et al. (1990) has valves semi-lanceolate and strongly dorsiventral. This genus is different from Amphora EHRENBERG ex KüTZING sensu lato by containing two elongated plastids of unequal size and uniseriate striae, which have apically elongate areolae (slit-like). Cymbella C. AgardH sensu lato and Encyonema KüTZING sensu lato present the same valvar shape. However, Seminavis has neither stigmata nor pore fields and it has both proximal and distal raphe ends dorsally deflected.

The morphology of the plastids, the internal raphe sternum with lateral fissure, the presence of accessory rib, and slit-like areolae are the main features that approach Seminavis to Navicula BORY sensu stricto, both genera are separated by dorsiventral lateral symmetry (Cox \& ReID 2004).

After the initial description of Seminavis, eighteen species were combined and discovered in this genus occurring in marine and brackish waters (Round et al. 1990; Danielidis \& MANN 2002, 2003; Cox \& Reid 2004; Danielidis et al. 2006; Garcia 2007; Wachnicka \& Gaiser 2007; WitKowsKi et al. 2000). Up to now, the species recorded from Brazil are $S$. atlantica Garcia by Garcia (2007) and SouzA-
Mosimann et al. (2011), S. robusta Danielidis et ManN (as Amphora angusta Gregory and Amphora angusta var. ventricosa (Gregory) Cleve) by MoreiraFilho (1959), Moreira-Filho \& KutNer (1962) and Fernandes et al. (1990), and S. strigosa (Hustedt) Danielidis et Economou-Amilli by Silva et al. (2010).

The low number of Seminavis species found in Brazil is probably related to the few taxonomic studies performed on the coast and probably due to the little attention given to rare taxa. The review of similar genera like Amphora and Cymbella can increase the species number and contribute to delimitate the Seminavis genus (Danielidis \& Mann 2003; Cox \& REID 2004).

Cymbella (Encyonema) grossestriata O. MüLLER var. recta FRENGUELLI was originally illustrated by Frenguelli (1938, plate I, fig 20) based on material from the Matanza river estuary (Argentina). Metzeltin et al. (2005) found this variety in Laguna Rocha (Uruguay) and proposed a new name to the taxon (Navicula norae Metzeltin, Lange-Bertalot et GARCIA-Rodriguez), justi-fying that this variety could not be combined intra-specifically with Cymbella grossestriata O. MülLER since it does not belong to the genera Cymbella C. Agardh or Encyonema KütZING. The epithet "recta" was not used because it 
was already established as the species Navicula recta BRun et Heribald. Afterwards the taxon was recorded as Cymbella grossestriata by SILVA et al. (2010) for southern Brazil. However, when specimens found in salt marshes from Brazil and the type material of Cymbella (Encyonema) grossestriata var. recta from Dr. J. Frenguelli Collection (LP, Museo de La Plata, Argentina) were analyzed in light and electron microscopy, we observed that both do not belong either to Cymbella (or Encyonema) or to Navicula, but rather to the Seminavis genus. Therefore, the transfer of this taxon to Seminavis is proposed.

\section{Materials and Methods}

Samples were gathered from surficial sediment and from stems of herbaceous plants (see list in Table 1) in three sites located in the salt marshes of the Patos Lagoon estuary ( $31^{\circ} 57^{\prime} \mathrm{S}, 52^{\circ} 06^{\prime} \mathrm{W}$ ) in southern Brazil (Fig. 1). The sampling was carried out in September 2010 (winter) and February 2011 (summer).

For the analysis of the epipelon the surficial sediment was collected with a core (10 $\mathrm{cm}$ of diameter; $2 \mathrm{~cm}$ of depth) and at the same time the $\mathrm{pH}$, salinity and temperature were measured in the interstitial water using $\mathrm{pH}$ meter $\left(\mathrm{PHTEK}^{\circledR}\right)$, salinometer $\left(\mathrm{YSI}^{\circledR} 30\right)$ and thermometer $\left(\right.$ Incoterm $\left.^{\circledR}\right)$. In laboratory, live motile diatoms were isolated from sediment by the "Trapping method" adapted from Eaton \& Moss (1966) and Laudares-Silva \& Cimardi (1989).

Epiphyton was scraped from plant stems using a metal blade. The scraped sections corresponded to the 5 $\mathrm{cm}$ portions of the stem adjacent to the ground which were submerged at the moment of sampling. The material was fixed with formaldehyde (4\%) after collection.

Epipelic and epiphytic samples were processed using nitric acid and mounted on slides using Naphrax ${ }^{\circledR}$. For light microscopy (LM) analysis we used a Zeiss Axioplan LM with a Axiocam ERc 5s camera. For scanning electron microscopy (SEM) a Jeol JSM-5200 (20 mm working distance, $15 \mathrm{kV})$ and a Jeol JSM-6060 (10 mm working distance, $20 \mathrm{kV})$ were used. Permanent slides are held at the Diatom Collection of Herbarium HAS (accession numbers 6242-6264; 64976517), Museu de Ciências Naturais, Fundação Zoobotânica do Rio Grande do Sul, Porto Alegre, Brazil.

The investigated material included five slides and raw material from the type of Cymbella (Encyonema) grossestriata var. recta from the Herbarium of the División

Table 1. Distribution of the Seminavis recta on epipelon and epiphyton along the sites [(IP) Ilha da Pólvora, (SS) Saco do Silveira and (SJN) São José do Norte] in winter 2010 and summer 2011, and physical and chemical data of the interstitial water.

\begin{tabular}{|c|c|c|c|c|c|c|}
\hline Samples & Epipelon & Epiphyton & Sanility & Temperature & pH & Plants \\
\hline \multicolumn{7}{|l|}{ winter } \\
\hline IP $1 \mathrm{~A}$ & $\mathrm{X}$ & $\mathrm{X}$ & 3.4 & 16.7 & 7.3 & Scirpus maritimus L. \\
\hline IP $1 \mathrm{~B}$ & $\mathrm{X}$ & $\mathrm{X}$ & 3 & 15.4 & 7.2 & Spartina densiflora BRONGN. \\
\hline IP $1 \mathrm{C}$ & $\mathrm{X}$ & $\mathrm{X}$ & 1.5 & 15.9 & 6.8 & S. maritimus \\
\hline SS $2 \mathrm{~A}$ & 0 & 0 & 0.1 & 20.6 & 8.8 & Juncus kraussii Hochst. \\
\hline SS 2B & 0 & 0 & 0.3 & 21.2 & 7.8 & J. kraussii \\
\hline SS 2C & 0 & 0 & 0.3 & 20.4 & 7.1 & S. densiflora \\
\hline SJN 3A & 0 & 0 & 1.2 & 17 & 7.2 & Spartina alterniflora LOISEL. \\
\hline SJN 3G & 0 & 0 & 1.9 & 19.1 & 7.7 & S. alterniflora \\
\hline SJN $3 i$ & 0 & 0 & 1.9 & 21.5 & 7.7 & S. densiflora \\
\hline \multicolumn{7}{|l|}{ summer } \\
\hline IP $1 \mathrm{~A}$ & $\mathrm{X}$ & $\mathrm{X}$ & 14 & 28 & 8.6 & S. alterniflora \\
\hline IP $1 \mathrm{C}$ & $\mathrm{X}$ & $\mathrm{X}$ & 8 & 29 & 6.6 & S. maritimus \\
\hline IP $1 \mathrm{~K}$ & 0 & 0 & 19.5 & 25 & - & S. alterniflora \\
\hline SS $2 \mathrm{~A}$ & 0 & 0 & 15 & 27 & 7.9 & J. kraussii \\
\hline SS 2D & 0 & 0 & 16 & 25 & 7.5 & J. kraussii \\
\hline SS $2 \mathrm{~F}$ & 0 & 0 & 15 & 26 & 6.8 & S. densiflora \\
\hline SJN 3D & 0 & 0 & 35 & 27 & 7.3 & S. alterniflora/J. kraussii \\
\hline SJN 3G & 0 & 0 & 30 & 27 & - & S. alterniflora \\
\hline SJN $3 i$ & $\mathrm{X}$ & $\mathrm{X}$ & 15 & 28 & 7.4 & S. alterniflora \\
\hline
\end{tabular}




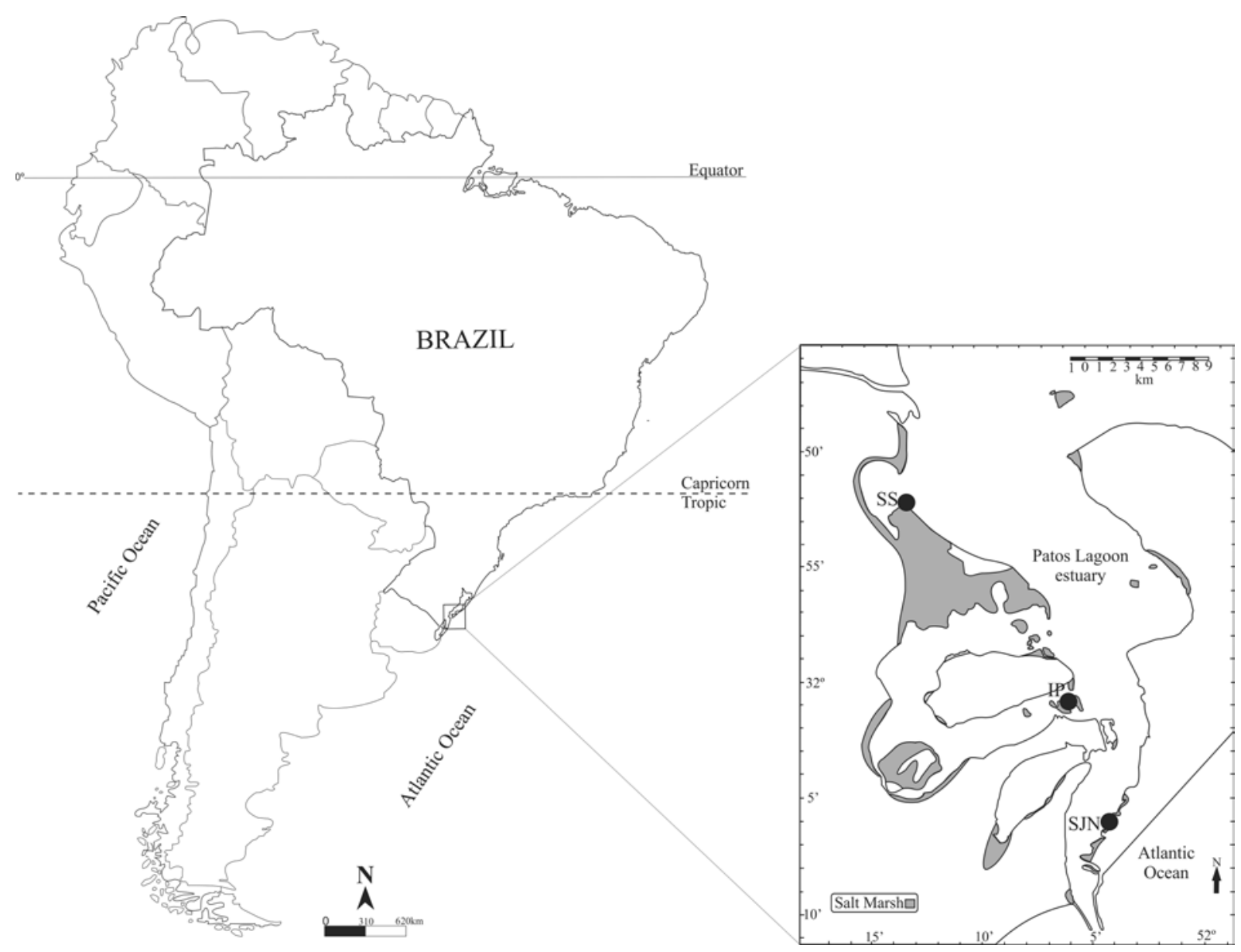

Fig. 1. Location of sampling sites [(SS) Saco do Silveira; (IP) Ilha da Pólvora and (SJN) São José do Norte] in salt marshes at Patos Lagoon estuary, southern Brazil. Modified from CosTA (1998).

Ficología of the Faculdad de Ciencias Naturales y Museo (LP), collection Dr. J. Frenguelli (series 403). The slides were observed using a Leica DM 2500 with DIC (Differencial Interference Contrast) and camera Leica DFC $420 \mathrm{C}$ located at the Faculdad de Ciencias Naturales y Museo de La Plata, Argentina. Small portion of raw sample were prepared and mounted on stubs to observe under SEM.

Morphological terminology follows ANONYMOUS (1975), BARBER \& HAWORTH (1981), Round et al. (1990) and DANIELIDIS \& MANN (2002). All figures were assembled using Corel Designer X6 ${ }^{\circledR}$.

\section{Results ANd Discussion}

Seminavis recta (Frenguelli) Talgatti et Torgan comb. et stat. nov. (Figs 3-44)

Basionym: Cymbella (Encyonema) grossestriata O. MüLLER var. recta Frenguelli 1938. Revista del Museo de La Plata, nueva serie 1, Paleontologia 5, p. 303, lam. I, fig. 20.

Synonym: Navicula norae Metzeltin, Lange-Bertalot \& GARCíA-Rodríguez 2005. Diatoms of Uruguay, Iconographia Diatomologica, Volume 15, p.138, figs 43: 1-5.

Original description: "Valvis asymmetrice lanceolatis, apicibus rectis, subcuneato-rotundatis; 90-93 $\mu$ longis, $20 \mu$ latis: striis transversis transverse lineolatis, validis, radiantibus, in valvae medio 4-5, ad apices 7 in $10 \mu$, lineolis 16-17 in $10 \mu$. Ceterum ut in typo."

Type locality: Argentina, Matanza river estuary in Buenos Aires, 12 February 1928 (LP 403).

\section{Morphology}

Light microscopy: The valves are dorsiventral, semilanceolate with dorsal margin arched and ventral margin slightly convex. The ends are rounded to cuneate and slightly arched to straight towards the center of the valve (Figs 3-35). The cell contains two plastids, one lying along each side of the girdle, which in valvar view shows long strips next to the border of the dorsal and ventral side; the dorsal plastid is larger than the ventral (Fig. 8). The central area is expanded and asymmetric, from circular to elliptic (Figs 17, 20) or not expanded but widening on the dorsal side following the axial area and on the ventral side it is rounded (half circle) (Figs 15, 28, 35). The striae are slightly radiate at the ends, becoming strongly radiate, and sigmoid in the center of the valve (Figs 7b, 13, 16, 
$32,35)$. In some specimens at the valve center there are one or two shortened striae that can be at the dorsal or ventral side (Figs 7b, 11, 16, 18). Length 61.8-110.94 $\mu \mathrm{m}$, width $12.5-18.3 \mu \mathrm{m}$. Dorsal central striae 5-7 in $10 \mu \mathrm{m}$, ventral central striae 5-8 in $10 \mu \mathrm{m}$, at the ends $7-8$ in $10 \mu \mathrm{m}$.

Electron microscopy: In external view, the raphe is filiform and straight until near the middle of the valve, where it is slightly deflected to the ventral side (Fig. 38). The proximal and distal raphe ends are dorsally deflected to secondary side, where the Voigt fault is. (Figs 36-40). The proximal raphe ends are slightly expanded and drop-like (Fig. 38). The distal raphe ends are strongly hooked onto the secondary side (Figs $40,42)$. The axial area is narrow and slightly raised (Fig. 38, 39). The areolae are apically elongate, slitlike $(22-24$ in $10 \mu \mathrm{m})$ starting on the mantle margin and following until the axial area, except at in the center of dorsal and ventral side where shortened striae are usually found (Figs 39, 41, 44).

In internal view, the proximal raphe ends appear continuous. The distal raphe ends terminate in the helictoglossa (Fig. 43). The raphe canal is accompanied by an accessory rib in the primary side, which is wider (expanded) at the center and is not interrupted (Fig. 44). A simple pore is observed at the apices (Fig. 43). The valves have a marked virgae (Fig. 44). The areolae are elliptical, occluded and together with vimines are strongly lower than the virgae (Fig. 44).

\section{Comparison with the type material}

Frenguelli (1938) when described C. grossestriata var. recta compared this taxon with other varieties of the species and concluded that the differences between them were the apices and the ventral side shapes. Cymbella grossestriata var. obtusiuscula MüLLER and C. grossestriata var. javanica Hustedt have oblique apices and ventral side with straight or gibbous edges, whereas $C$. grossestriata var. recta has apices gradually cuneate (never rostrate) and convex edge in ventral side (Figs 3-35).

The rare specimens found in the sample number 403 from Frenguelli Collection (Figs 3-7c) were broken, but it was possible to relate them to the authors's drawing (Fig. 2). We also found smaller specimens in this Collection (Table 2), with a higher number of the striae and lineolae than those recorded by FrENGUELLI (1938). Such specimens have similar dimensions and shape to those of Brazilian (Figs 8-35) and Uruguayan material (Table 2). However, some specimens from the Frenguelli Collection have shortened striae at the center of the valve, like the specimens from the Brazilian salt marsh, which can be viewed using light microscope (Figs 5b, 7b, 11, 16, 18). In the specimens showed by Metzeltin et al. (2005; plate 43, figs. 1-4) the presence of these shortened striae is not clear. The observation of these striae probably is related with the position of

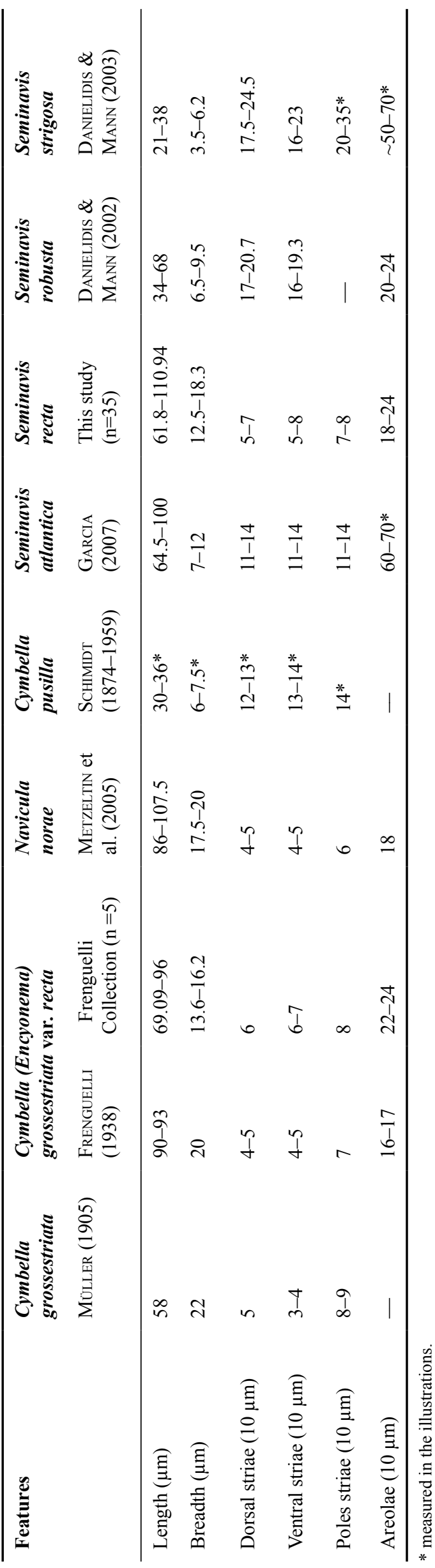




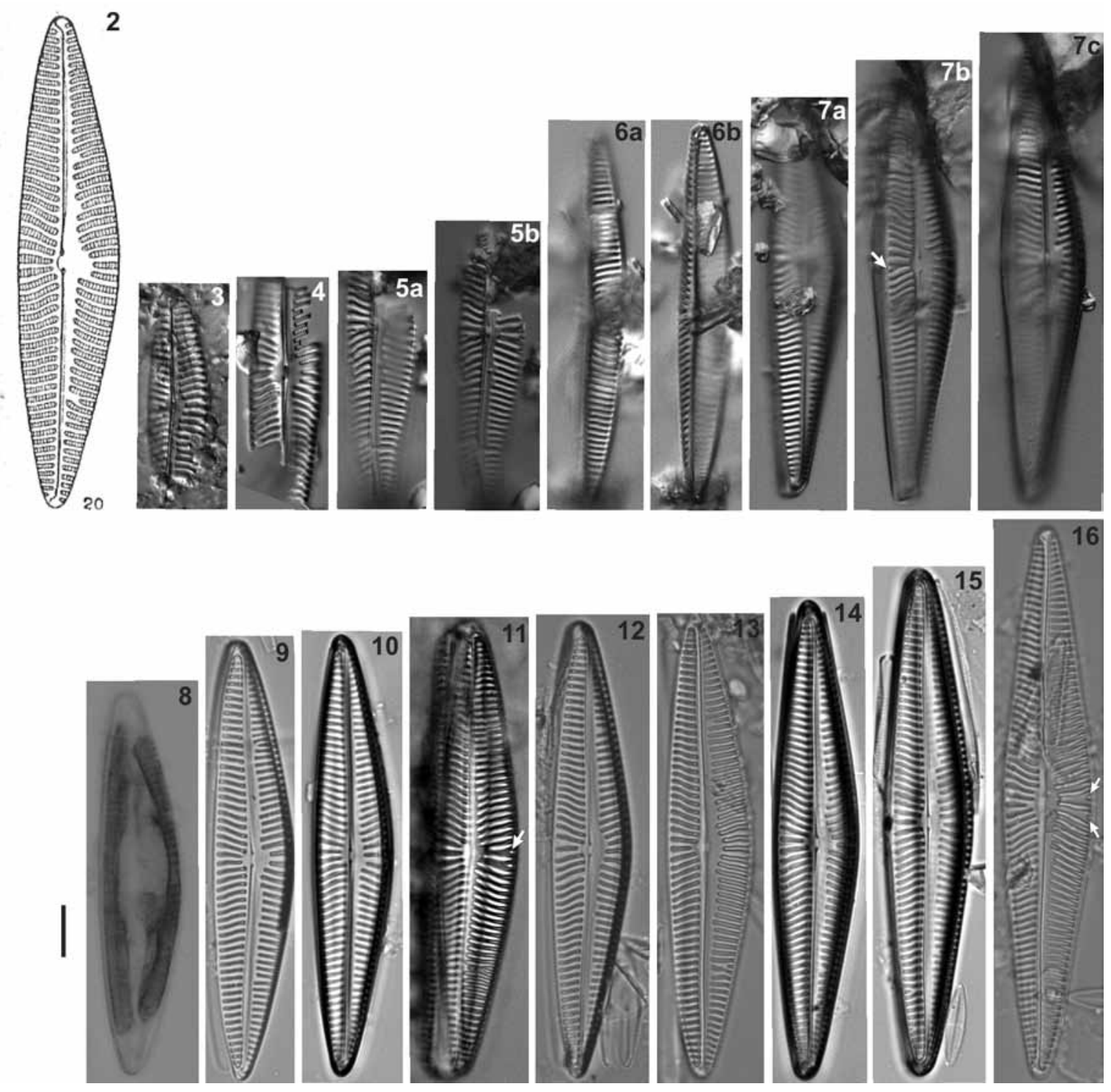

Figs 2-16. LM images of Seminavis recta comb. nov et stat. nov.; (2) iconotype of the Cymbella grossestriata var. recta by Frenguelli (1938, fig. 20) showing specimen in valvar view; (3-7c) images of specimens from the Frenguelli Collection (type, sample 403, LP); (7b) arrows indicate shortened striae in ventral side; (8-16) epipelic specimens from Brazilian salt marshes; (8) image showing cell containing two plastids; (11) arrows indicate shortened striae in dorsal side. Scale bar $10 \mu \mathrm{m}$.

the valve on the slide, nevertheless during the analysis of the individuals on SEM it was possible to visualize that these shortened striae are on the valve mantle (Fig. 41). Our efforts to observe unmounted material from the type collection of $C$. grossestriata var. recta in SEM was unsuccessful because the material was rare in the sample, as mentioned also by FrENGUELLI (1938).

\section{Comparison with similar taxa}

Cymbella grossestriata MüLLER differs morphologically from Seminavis recta by shorter length, greater breadth, ventral side with gibbous edge, dorsal and ventral striae strongly divergent and poles narrowly rounded (Table 2).

Cymbella pusilla GRUNOw (in SCHIMIDT 1874-1959) was illustrated in electronic microscopy by Cox (1979), and it was transferred to Seminavis by Cox \& REID
(2004) based on a cladistic analysis. Seminavis pusilla (Grunow) Cox et ReID and $S$. recta have a similar shape, however the first one shows smaller dimensions and more delicate striations (Table 2).

Seminavis atlantica GARCiA can be distinguished from $S$. recta by denser striae and areolae and a different valve outline (see GARCIA 2007; fig. 10). In $S$. atlantica the ventral margin is slightly concave and the dorsal margin is convex-linear, while in S. recta the ventral margin is slightly convex and the dorsal margin is strongly arched.

Seminavis robusta DANIELIDIS et MANN presents smaller dimensions and higher striae density (16-19.3 striae in $10 \mu \mathrm{m}$ ) than $S$. recta. Furthermore, S. robusta has a broad axial area at the dorsal side and internally does not have expanded accessory rib at the center of the valve (see DANIELIDIS et MANN 2002; figs 49, 51). 

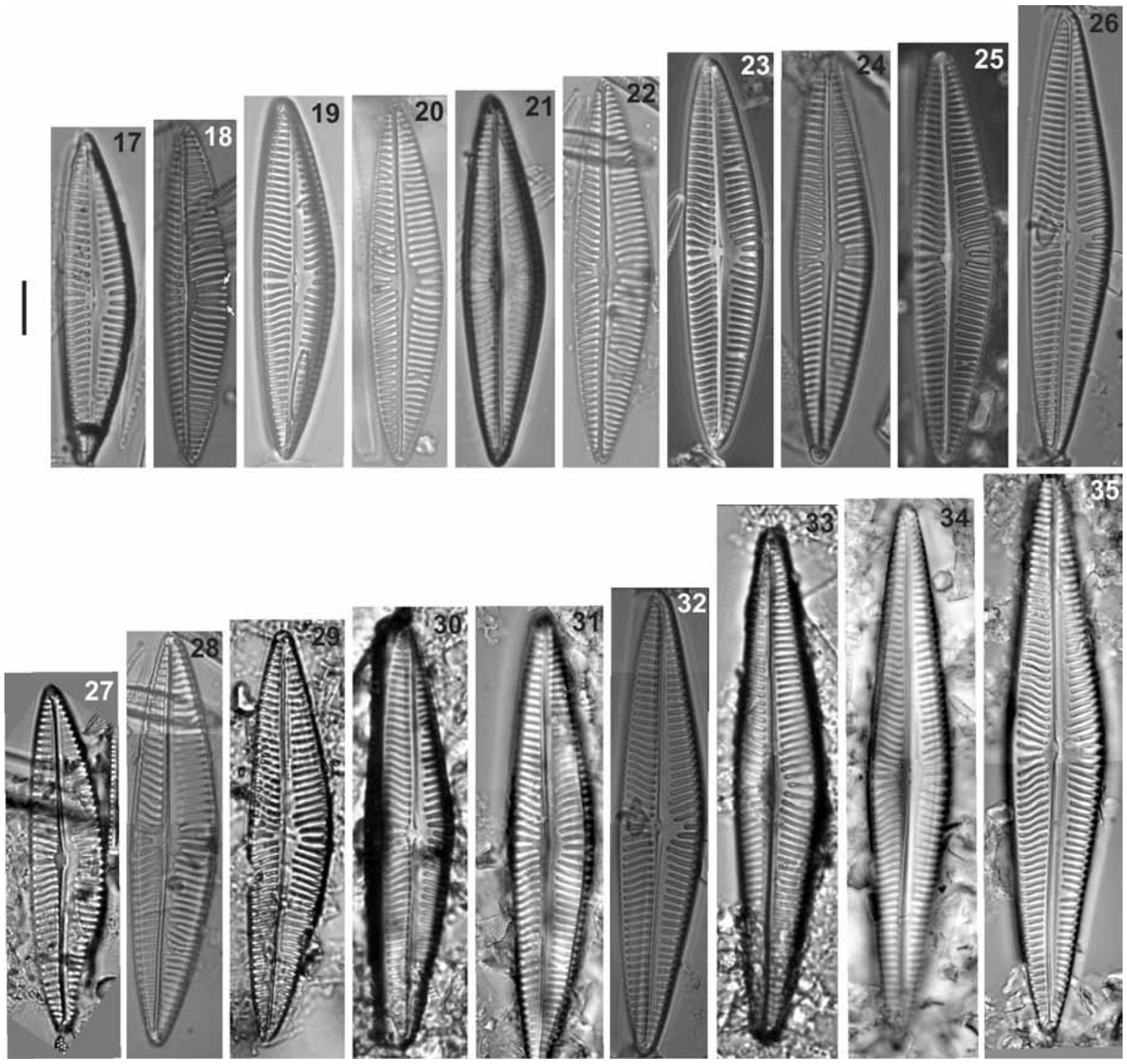

Figs 17-35. LM images of Seminavis recta comb. nov et stat. nov.; (17-35) specimens from Brazilian salt marshes; (17-26) images of the specimens from the epipelon; (17) arrows indicate shortened striae in ventral side; (27-35) images of the specimens from the epiphyton. Scale bar $10 \mu \mathrm{m}$.

Seminavis strigosa (HustedT) DANIELIDIs et ECONOMOU-AMILLI presents shorter dimensions and has a higher striae and areolae density than S. recta (Table 2). Furthermore, the first species shows a straight ventral margin and central area more expanded.

\section{Ecology and distribution}

Seminavis recta occurred concomitantly in the epipelon and epiphyton (Table 1). The species was found alive in temperatures between $15.4{ }^{\circ} \mathrm{C}$ and $29^{\circ} \mathrm{C}, \mathrm{pH}$ between 6.6 and 8.6, and in oligo to mesohaline zone (salinity between 1.5 and 15) (Table 1). It is important to point out that $S$. recta did not show specificity with any kind of plant, occurring in association with Spartina alterniflora LoIsel., S. densiflora BRONGn. and Scirpus maritimus L. (Table 1).

Seminavis recta from Brazilian salt marshes was found in sediment composed by sand and clay.
In the estuary of Matanza river (Argentina) where the species was first described, and in Laguna Rocha (Uruguay) a shallow lagoon with a wide salinity range (Metzeltin \& García-Rodriguez 2003) the sediment is also composed by clay and sand.

Afterwards, SiLva et al. (2010) recorded $S$. recta (as Cymbella grossestriata) for the salt marshes of Patos Lagoon estuary. The authors found this species in summer and autumn, in the oligohaline zone (salinity= 5), with temperature ranging between $24.1{ }^{\circ} \mathrm{C}$ and $27.1{ }^{\circ} \mathrm{C}$ and the $\mathrm{pH}$ between 5.3 and 7.3 (personal communication).

The occurrence of living individuals of $S$. recta in a wide range of salinity and simultaneously in the epipelon and epiphyton should be related to the system's dynamics. The salt marshes of the Patos Lagoon estuary endure a constant variation of the water level and of salinity which depends on the 

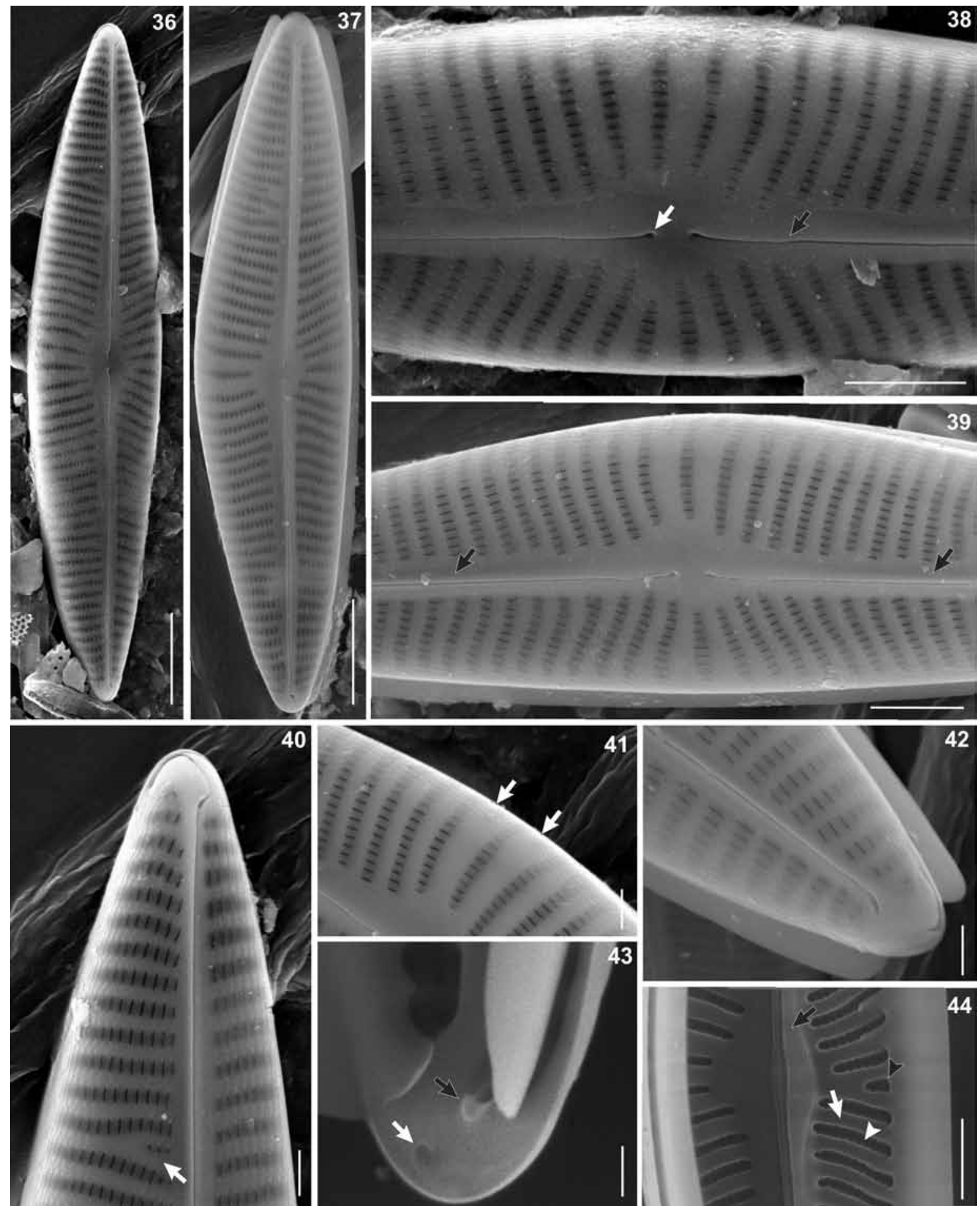

Figs 36-44. SEM images of Seminavis recta comb. nov et stat. nov. (material from Brazilian salt marshes): $(36,37)$ external view of the valve; (38) external view of the center of the valve showing the raphe slightly deflected to ventral side (black arrow) and proximal raphe ends slightly expanded and drop-like (white arrow); (39) shape of central area, striae pattern and axial area slightly raised (black arrow); (40) apice of valve showing distal raphe ends strongly hooked onto secondary side and Voigt fault (white arrow); (41) detail of the center of the dorsal side showing two shortened striae onto the valve mantle (white arrow); (42) detail of distal raphe ends deflected to dorsal side; $(43,44)$. Internal view of the valve; (43) distal raphe ends terminated in helictoglossae (black arrow) and apical simple pore (white arrow); (44) center of valve showing accessory rib expanded to ventral side and no interrupted (black arrow), a thickened virgae (white arrow), vimines (white arrow head) and shortened stria in the ventral side (black arrow head). Scale bars $10 \mu \mathrm{m}(36,37) ; 5 \mu \mathrm{m}(38,39,41) ; 2 \mu \mathrm{m}(40,42) ; 1 \mu \mathrm{m}(43,44)$. 
meteorological conditions (direction of wind and pluviosity) in the region.

\begin{abstract}
ACKNOWLEDGements
We thank CAPES (Coordenação de Aperfeiçoamento de Pessoal de Nível Superior) for a doctoral grant to the first and second authors. To César Serra Bonifácio Costa, Instituto de Oceanografia, Laboratório de Ecologia Vegetal Costeira, Universidade Federal do Rio Grande, for support and help in fieldwork and to the Centro de Microscopia Eletrônica at the Universidade Federal do Rio Grande do Sul (UFRGS) for SEM support. We are also thankful to Dr. Martha E. Ferrario and Lic. José María Guerrero, División Ficología, Collection of the Dr. Joaquín Frenguelli of the Museo de La Plata (Argentina) for providing the Frenguelli's type material of Cymbella (Encyonema) grossestriata var. recta, to Dr. Eugenia A. Sar and Dr. Inês Sunesen, División Ficología, Universidad Nacional de La Plata (Argentina) for technical support. We appreciate Dr. H. D. Laughinghouse IV and R. M. Fischer for reviewing the English text.
\end{abstract}

\section{REFERENCES}

Anonymous (1975): Proposals for standardization of diatom terminology and diagnoses. - Nova Hedwigia, Beiheft 53: 323-354.

Barber, H.G. \& Haworth, E.V. (1981): A guide to the morphology of the diatom frustule with a key to the British freshwater genera. - Freshwater Biological Association Scientific Publication 44: 1-112.

Costa, C.S.B. (1998): Irregularly flooded marginal marshes. - In: Seeliger, U.; odebrecht, C. \& Castello, J. P. (eds): Subtropical convergence environments: the coast and sea in the Southwestern Atlantic. - pp. 72-77, Berlin, Springer-Verlag.

Cox, E.J. (1979): Symmetry and valve structure in naviculoid diatoms. - Nova Hedwigia, Beiheft 64: 193-206.

Cox, E.J. \& REID, G. (2004): Generic relationships within the Naviculineae: A Preliminary Cladistic Analysis. - IN: Poulin, M. (ed): Proceedings of the $17^{\text {th }}$ International Diatom Symposium, Ottawa, Canada, August 2002. - pp. 49-62, Biopress Limited, Bristol, U.K.

Danielidis, D.B. \& Mann, D.G. (2002): The systematics of Seminavis (Bacillariophyta): the lost identities of Amphora angusta, A. ventricosa and A. macilenta. Eur. J. Phycol. 37: 429-448.

Danielidis, D.B. \& ManN, D.G. (2003): New species and new combinations in the genus Seminavis (Bacillariophyta). - Diatom Res. 18: 21-39.

DANIELIDIS, D.B.; Ford, K. \& KenNeTt, D. (2006): Transfer of Amphora eulensteinii Grunow to the genus Seminavis D. G. Mann. - Diatom Res. 21: 71-80.

Eaton, J.W. \& Moss, B. (1966): The estimation of numbers and pigment content in epipelic algal populations. Limnol. Oceanogr. 11: 584-595.

Fernandes, L.F.; Souza-Mosimann, R.M. \& Fernandes, G.F. (1990): Diatomáceas (Bacillariophyceae) do Rio Ratones, Florianópolis, Santa Catarina, Brasil I-baixo curso e estuário. - Ínsula 20: 11-112.

Frenguelli, J. (1938): XIII Contribución al conocimento de las diatomeas argentinas. Diatomeas del Querandinense Estuarino del Río Matanza em Buenos Aires. - Rev. Mus. La Plata (n.s.) 1, Paleontología 5: 291-314.

Garcia, M. (2007): Seminavis atlantica Garcia, a new psammic diatom (Bacillariophyceae) from southern
Brazilian sandy beaches. - Braz. J. Biol. 67: 765769.

Laudares-Silva, R. \& Cimardi, J.M. (1989): Nota sobre a utilização do "Trapping Method" no estudo das diatomáceas epipélicas do manguezal de Ratones Florianópolis - SC. - Ínsula 19: 299-304.

Metzeltin, D. \& García-Rodriguez, F. (2003): Las Diatomeas Uruguayas. - 207 pp., D.I.R.A.C. Ediciones, Faculdade de Ciencias, Montevideo.

Metzeltin, D.; Lange-Bertalot, H. \& García-Rodríguez, F. (2005): Diatoms of Uruguay. - Iconogr. Diatomol. 15: $1-736$.

Moreira-Filho, H. (1959): Diatomáceas do Paraná - I. A flora diatomológica no Sargassum. - Boletim do Instituto de História Natural 1: 1-22.

Moreira-Filho, H. \& KutNer, M. (1962): Contribuição para o conhecimento das diatomáceas do manguesal de Alexandra. - Boletim da Universidade do Paraná, Bot. Curitiba 4: 1-24.

MüLlER, O. (1905): Bacillariaceen aus dem Nyassaland und einigen benachbarten Gabieten. III Folge, Naviculoideae-Naviculeae-GomphoneminaeGomphocymbellinae-Cymbellinae. NitzschioideaeNitzschieae. - (Engler's) Botanische Jahrbucher fur Systematik, Pflanzengeschichte, und Pflanzengeographie 36: 137-206.

Round, F.E.; Crawford, R.M. \& Mann, D.G. (1990): The Diatoms. Biology \& morphology of the genera. -741 pp., Cambridge University Press, Cambridge.

Schimidt, A. (1874-1959): Atlas der Diatomaceen-Kunde, Reisland: Leipzig.

Silva, J.G.; Torgan, L.C. \& Cardoso, L.C. (2010): Diatomáceas (Bacillariophyceae) em marismas no sul do Brasil. - Acta Bot. Bras. 24: 935-947.

Souza-Mosimann, R.M.; Laudares-Silva, R.; Talgatti, D. \& D'Aquino-Rosa, V. (2011): The diatom flora in Conceição Lagoon, Florianópolis, SC, Brazil. Ínsula 40: 25-54.

Wachnicka, A. \& Gaiser, E. (2007): Characterization of Amphora and Seminavis from south Florida, U.S.A. - Diatom Res. 22: 387-455.

Witkowski, A.; Lange-Bertalot, H. \& Metzeltin, D. (2000): Diatom flora of marine coasts I. - Iconogr. Diatomologica 7: 1-925.

(C) Czech Phycological Society (2014)

Received December 27, 2013

Accepted February 13, 2014 